\title{
Young characters in television fiction: \\ Youth identities, models and portrayals in the digital age \\ RESEARCH REPORT
}

Alianza 4 Universidades Postdoctoral Grant

\author{
Department of Communication \\ Universitat Pompeu Fabra \\ PhD. Maddalena Fedele \\ CAS (Communication, Advertising \& Society) Research Group \\ www.cas.upf.edu
}

September 2014 
Aquest document està subjecte a una llicència Creative Commons - Reconeixement-NoComercial 4.0 Internacional Doi: $10.31009 /$ informesdcom.2020.02 


\section{Abstract}

This report paper presents the study "Young characters on television fiction: identities, models and portrayals in the digital age", which was carried out within the CAS research group at the Department of Communication, Universitat Pompeu Fabra, in the framework of the Postdoctoral Grant Alianza 4 Universidades.

The analysis of fiction programmes specifically targeted at teenagers (i.e. teen series) is a key research field still in the digital age, from both production and reception perspectives.

On the one hand, teen series are key media products around youth culture, and often pioneer in the complex technological and cultural crossroads of the digital era. On the other hand, a significant body of literature has stressed young people's preference for fiction programmes and especially for teen series, and the very influence of television fiction in teenagers' socialisation processes. Also, previous studies pointed out the perpetuation of traditional and stereotyped models in the portrayals of female and male characters of fiction programmes.

The main aims of the study were to analyse the teen series format, as well as the portrayals of ten and young characters and their storylines.

The study consisted of a content analysis (through both quantitative and qualitative techniques) of the American, British and Spanish teen series available in Spain in the period 2008-2012, and its leading characters. A content analysis of 40 teen series and 130 young protagonists was carried out, with the help of SPSS and Atlas.ti.

Among the main results about the teen series format, a common convergence on the dramatic and the fantastic genres has to be pointed out, as well as a complex cross-media strategy.

Nevertheless, several differences in the length, the format and the scheduling strategy of American/British and Spanish programmes must be emphasised.

As for the teen characters, the perpetuation of patriarchal and heteronormative gender stereotypes has to be emphasised, especially related to physical and sociodemographic characteristics. Nevertheless, while a more equal gender portrayal can be found in the psychological characteristics, as well as in the analysis of storylines and plots.

\section{Key-words}

Teen series, Television fiction programmes, Teens, Adolescents, Young people, Gender, Characters 


\section{INDEX}

1. Introduction: Adolescents and teen series 7

2. Presenting the project 9

$\begin{array}{ll}\text { 3. Literature Review } & 10\end{array}$

4. Objectives and methodology 12

$\begin{array}{lr}\text { 5. Results } & 19\end{array}$

5.1. Analysis of the teen series format 19

5.2. Analysis of the teen characters 23

5.3. Analysis of the storylines 27

$\begin{array}{lr}\text { 6. Works cited } & 29\end{array}$

$\begin{array}{ll}\text { 7. Annexes } & 33\end{array}$

7.1. Annex 1: List of the teen series analysed in phase 3

7.2. Annex 2: List of teen series analysed in phases 4 and 6

7.3. Annex 3: List of teen series characters analysed 35

7.4. Annex 4: Coding system for teen series 38

7.5. Annex 5: Coding system for space variables 39

7.6. Annex 6: Coding system for teen characters 40 


\section{Introduction: Adolescents and Teen series}

Adolescence is a key stage in the development and construction of values and identities, both individual and collective. Throughout this delicate, complex process, individuals frequently turn to models and representations provided by significant others in their environment, known as socialising agents. These agents include communications media.

Alongside new digital media, television continues to exert considerable influence in adolescent socialisation processes in the Digital Age. This is most apparent when it comes to fiction programmes, which, indeed, are at the top of young people's list of preferences, as many studies have demonstrated (Fedele, 2011; Garitaonandia et al., 1998; Livingstone, 1998; Medrano-Samaniego, Palacios-Navarro and AierbeBarandiarán, 2007; Pindado, 2006; Ramírez de la Piscina et al., 2006; von Feilitzen, 2004).

It is also important to bear in mind that television fiction programmes are increasingly available at a global level through various technological platforms, which today's youth, digital natives, habitually use in their consumption, which is multimedia, multiscreen, and multitasking. Online fiction consumption, in particular, grants them access to foreign television shows that are not broadcast on Spanish DTT channels, including many US titles, for example.

As a result of this, content analysis of audio-visual fiction, both domestic and foreign, is a key instrument to monitor the representations that are being offered to audiences. More specifically, the need is increasingly making itself felt for analysis of television shows being directed at, and consumed by, a teenage audience: the models and stereotypes of adolescence which are consumed by teenagers need to be understood. Since the prototype of television fiction programme favoured by adolescents is the socalled "teen series" (Davis and Dickinson, 2004; Fedele, 2011; García-Muñoz and Fedele, 2011a and 2011b; Mosely, 2011; Ross and Stein, 2008), those serialised fiction programmes that tell the stories of teenage characters and are addressed at a teen audience, deeper study is needed of the representations of adolescence which these programmes contain. 
On the one hand, teen series are key media products around youth culture, and often pioneer in the complex technological and cultural crossroads of the digital era, being able of taking the advantage of phenomena and processes such as digitisation and convergence, distribution and global circulation of media products, hybridisation of media genres, commercialisation of commodity and leisure (Caldwell, 2004; Carlsson, 2006; Spigel and Olsson, 2004). This "post-broadcast era" context provides the ideal scenario for new typologies of television programmes and television consumption coexisting with more traditional ones, as in the case of teen series. On the other hand, a significant body of literature has stressed young people's preference for fiction programmes and especially for teen series, and the very influence of television fiction in teenagers' socialisation processes (e.g.: Arnett, Larson and Offer, 1995; Gerbner et al., 2002; Maira and Soep, 2004).

The research proposed here takes the postdoctoral candidate's prior work as its starting point: an analysis of serialised fiction consumption by adolescents and a case study of the US teen series Dawson's Creek. Firstly, this study is based on her doctoral thesis, El consum adolescent de la ficció seriada televisiva, [Adolescent consumption of serialised television fiction], defended in 2011 in the Department of Audio-visual Communication and Advertising at the Autonomous University of Barcelona (Fedele, 2011). Secondly, her project incorporates various studies preceding the thesis, which focused on television programming targeting youth audiences. One of these is a 2004 analysis of programming on MTV Italia, carried out in collaboration with the Department of Communication Sciences at the University of Salerno (Fedele, 2009a). Another is the exploratory study on teen series carried out in the GRISS research group at the Autonomous University of Barcelona during the first phase of her pre-doctoral grant (Beca Fl, Generalitat de Catalunya) (Fedele 2009b; Fedele and García-Muñoz, 2010), which culminated in the case study of the US series Dawson's Creek (GarcíaMuñoz and Fedele, 2011a, 2011b and 2011c). 


\section{Presenting the project}

The project titled "Los personajes jóvenes en la ficción televisiva: identidades, modelos y representaciones juveniles en la era digital" [Young characters in television fiction: youth identities, models and representations in the digital age] consisted of a content analysis (combining quantitative and qualitative techniques) of media portrayals of young people in television fiction programmes targeted to teens, that is the teen series. A representative sample of the most recent Spanish and foreign teen series has been analysed, taken from those available to Spanish teens both by broadcast television and online in the period 2008-2012. Models and stereotypes of the teenage characters depicted have been analysed so as to describe the teenage identity transmitted to adolescents. Above all, attention has been given to whether gender and age stereotypes continue to be propagated, as previous studies have shown (GarcíaMuñoz and Fedele, 2011c), or if more recent shows offer new social models.

The project was carried out by the candidate at the Department of Communication, Universitat Pompeu Fabra, within the CAS (Communication, Advertising \& Society) research group (https://www.upf.edu/web/cas). Of great relevance was the incorporation in the analysis of categories previously used and confirmed by research done by other group members (Luzón-Fernández et al., 2009), as well as the supervision of youth and media expert Dr. Mònica Figueras Maz, and the meetings with Dr Pilar Medina and Dr Lluís Mas to discuss the methodological approach and the analysis categories. 


\section{Literature Review}

The study of how youth are represented in television fiction can be undertaken from the perspective of research that studies fiction programmes alongside other television shows in terms of their depiction of youth and/or adolescents. Another approach is that of research into specific fiction programmes.

For the first approach, studies of the depiction of youth in primetime programming predominate (Heintz-Knowles, 2000; Signorielli, 1987). The study of young characters' sexual behaviour has been of significant interest, not only social, but also academic (Aubrey, 2004; Meyer, 2003; Ward, 1995). The study of characters from a gender perspective is also of high interest in much research, especially regarding specific aspects like the depiction of bodies (Barriga, Shapiro and Jhaveri, 2009; Fouts and Burggraf, 2000; Fouts and Vaughan, 2002; Robinson, Callister and Jankoski, 2008), as well as general aspects (Glascock, 2001; Lauzen, Dozier and Horan, 2008; Signorielli and Bacue, 1999).

The contributions of fiction studies and youth studies have come, albeit to a lesser degree, from the analysis of specific case studies of television shows. Some noteworthy studies include those by Davis and Dickinson (2004) concerning teen series from the 1990s and those by Ross and Stein (2008) also concerning teen series, as well as other studies focused on specific titles.

In Spain, some outstanding studies include the analysis of gender stereotypes in two Spanish series by Galán-Fajardo (2007), the study by Belmonte and Guillamón (2008) about gender stereotypes in the series most frequently viewed by Spanish youth, the study by Ramajo et al. (2008) on teen representations on primetime television in Spain, the study by Guarinos (2009) about prototypical representations of teens in fiction products broadcast in Spain and targeted at a young audience, and the sitcom study carried out by Grandío-Pérez and Pedro-González (2009).

The majority of studies of the representation of adolescence on television, which have focused especially on fiction programmes, have emphasised the propagation of traditional and stereotypical roles (Aubrey, 2004; Belmonte and Guillamón 2008; Davis 
and Dickinson, 2004; Heintz-Knowles; 2000; Galán-Fajardo, 2007; García-Muñoz and Fedele, 2011c; Meyer; 2003; Ramajo et al., 2008; Guarinos, 2009; Rodrigo and Medina, 2009; Signorielli, 1987).

A relevant fact emerges regarding, specifically, the variable "gender". Social roles are significantly different: female characters are primarily depicted in terms of their family responsibilities and most often involved in situations involving love, family or friends; while male characters are more frequently identified with their professional roles (Lauzen, Dozier and Horan, 2008; Signorielli and Bacue, 1999, among others).

Female characters are often less frequently seen, or fewer in number, than male characters (Signorielli and Bacue 1999). Furthermore, the women portrayed tend to be younger than the men (Signorielli and Bacue 1999), thin and provocatively dressed (Fouts and Burggraf, 2000; Barriga, Shapiro and Jhaveri, 2009), and occupying positions or showing attitudes which are weaker or submissive, while men tend to be stronger and more powerful (Mastro and Ortiz, 2008). Other studies have shown that women tend to be depicted more often as victims of male violent episodes, and men tend to be shown as aggressors (Fernández-Villanueva et al., 2009) or as individuals with more propensities towards aggression (Scharrer, 2001).

It has been demonstrated that, in recent decades, the representation of female characters in television programs has improved, and that the presence of women "behind the camera" is contributing to this improvement, at least as regards fiction programmes (Lauzen, Dozier and Cleveland, 2006). Furthermore, the case study carried out by Dr Fedele, focusing on characters in the US teen series Dawson's Creek, demonstrated that new youth models and identities, which are more complex (especially psychologically) and more egalitarian in terms of gender, have made headway on occasion (García-Muñoz and Fedele, 2011c). 


\section{Objectives and Methodology}

The main project objective has been to identify models and stereotypes surrounding teen characters depicted in the most current teen series, in order to describe the youth identities they transmit to their young viewers, through programmes produced specially for them. Above all, the question addressed was whether the abovementioned gender and age stereotypes continued to be perpetuated, or if recent products are offering new social models.

Specifically, the project involved a series of sub-objectives:

- Survey the principle teen series available to Spanish audiences, both on traditional broadcast television and on digital platforms (computers and mobile phones);

- Conceptualise the main characteristics of current teen series by analysing characters and plots;

- Contribute to the theoretical definition and analysis of the teen series television format;

- Identify similarities and differences between teen series from different countries;

- Identify similarities and differences between characters in teen series produced in different countries;

- Identify physical, sociodemographic and psychological characteristics of youth/adolescent characters depicted in the teen series available to Spanish audiences;

- Identify principal themes in series storylines and plots and in the conflicts in which characters are involved;

- Analyse the attitude and role of characters within the plots and conflicts depicted;

- Analyse youth archetypes present in the diversity of teen series analysed;

- Analyse the locations in which these characters tend to be shown. 
The methodological design of the study included the following phases, developed throughout the two-year postdoctoral fellowship (Table 1. Calendar):

1) Phase 1. State of the art and sample selection, involving four sub-phases:

1.1. Development of the theoretical framework of the study. This sub-phase was carried out during the first few months of the fellowship (OctoberDecember 2012), with a focus on the presentation of teen characters in the television fiction products. Existing Spanish and international studies were analysed which had been published in prestigious journals, available on the databases ISI Web of Knowledge, Sage Journals Online, EBSCO Journals, Scopus SciVerse, In-Recs, Dice and Carhus Plus. The main search keywords were the following: adolescents, teenagers, teen series, character, character portrayal, character representation, adolescentes, jóvenes, series juveniles, personaje, representación de personaje, imagen de personaje, among others. Additionally, previous studies done by members of the host research group were analysed, and the researchers were personally consulted (Carrillo, Jiménez-Morales and Sánchez, 2011; Carrillo, Hernández and Jiménez-Morales, 2011; Figueras-Maz, Mauri-De Los Ríos and Rodríquez-Martínez, 2013; Gómez-Puertas, 2011; Masanet, Medina-Bravo and Ferrés, 2012; Mauri-De Los Ríos and Figueras-Maz, 2012; Medina-Bravo and Rodrigo, 2009; Ramajo et al., 2008).

1.2. Exploration of Spanish and US television schedules for the chosen sample period (2008-2012), in order to identify the most relevant titles belonging to the teen series format. This sub-phase was carried out in January and February 2013, in parallel with the one described in point 1.3. In the case of Spanish television networks, both generalist and youth not-for-pay channels were considered (i.e., DTT channels).

1.3. Exploration of online rebroadcasting services available in Spain (official sites of TV channels and streaming or downloading sites) in order to identify the most relevant titles in the teen series format. 
1.4. Selection of a representative sample of teen series and episodes to be analysed from the 50+ titles identified in sub-phases 1.2 and 1.3. This subphase was implemented in March 2013. The 40 teen series analysed in point 3 were selected in this phase. In the end, it was decided to include a few British series, given their presence in schedules and impact on Spanish audiences. Annex 1 lists the forty titles selected in this sub-phase and analysed in Phase 3 (analysis of the teen series format). Additionally, following the analysis of the teen series format (point 3), the twenty most representative teen series for the analysis of characters and storylines (points 4/5 and 6) were selected: five were Spanish, ten were from the US, and five were British. For each of these series, three episodes were chosen from their first season. Characters were analysed based on their development throughout the selected episodes (mixed-methods analysis of the characters and the storylines, respectively in points $4 / 5$ and 6). Storylines and plots were analysed based on the conflicts present in one of the three selected episodes. Annex 2 lists the twenty teen series analysed in phases 4,5 and 6.

2) Phase 2. Preparation and piloting of the instruments of analysis. Databases were prepared in SPSS, including descriptions and definitions related to the variables to be analysed. Three coding books for quantitative analysis were prepared (Annexes 4, 5 and 6), and an analysis notebook was kept for the qualitative analysis of protagonists' development in the analysed teen series. In April 2013, pilot studies were performed on the US teen series Beyond the Break (known as Surf girls in Spain), available in streaming, but it was removed from the sample in phases 4,5 and 6 because it had not been broadcast in its entirety on publicly available Spanish channels during the 2008-2012 period.

3) Phase 3. Mixed-methods analysis of the teen series format available in Spain on broadcast television and the Internet between 2008-2012, according to elements like genre, format, themes, characters, programming strategy and transmedia strategy. As mentioned in point 1.4, 40 teen series (Spain, US and UK) were chosen for analysis according to variables like channel and programming slot, genre and 
microgenre (following the Euromonitor classification as described by Prado and Delgado 2010), number, sex and ages of protagonists (tweens, adolescents, youth, young adults), individual or group protagonism, locations most often depicted, transmedia/multi-screen/crossmedia strategy (DVD, streaming availability on official website, social network presence, merchandising, among other things). This phase was implemented in May and June 2013, partially overlapping with point 4.

4) Phase 4. Quantitative content analysis for the first of the two project analysis units (characters): analysis of the protagonists of the 20 teen series selected, in order to measure different variables, among which the most important were:

- Physical characteristics of the characters (based on García-Muñoz and Fedele, 2011b and 2011c; Madrigal-Fritsch et al., 1999);

- Sociodemographic characteristics of the characters (based on García-Muñoz and Fedele, 2011b and 2011c);

- Psychological characteristics of the characters (based on the "big five" model by McCrae and Costa, 1999) and youth archetypes (own proposal based on film and television industry categories)

As mentioned above, the analysis of characters was based on a viewing of three episodes from the first season of the 20 most representative teen series from the sample, which were chosen beginning in phase 3 . The study focused on the protagonists of each teen series, which belonged to an age range representative of the teen and young population: tweens (10-13 years old), teens (14-19 years old) and youth (20-25 years old), a category which is currently quite present in recent titles, as was shown in phase 3. Phase 4 was implemented in June, July and August 2013. Annex 3 includes the list of characters analysed in phases 4 and 6.

5) Phase 5. Qualitative analysis of teen series characters' development over a season. For this phase, two case studies were chosen, one Spanish (EI Barco) and one from the US (The Vampire Diaries). This choice was made in accordance with the following aspects, analysed in phase 3 : 
- Very recent programmes (El Barco ended in 2013, while the fifth season of The Vampire Diaries will be broadcast in 2015);

- Diversity of genres (the first is a series and the second is a serial, at least in the first season); diversity of microgenres (Thriller/Suspense and Fantasy/Science Fiction, respectively);

- High number of main characters in the study's target age range, teens and youth (7 for the former and 9 for the latter);

- Group protagonism, strong protagonism of the teen group and dramatic importance given to young characters;

- Relevant transmedia strategy.

All episodes of the first season of these programs were viewed between September and December 2013, in order to analyse in-depth the personalities, values and behaviours of their protagonists. A file was kept on each character in the analysis notebook in order to track each character's development.

6) Phase 6. Qualitative content analysis for the second of the two analysis units mentioned above, storylines and plots shown in teen series, in order to measure various variables (based on García-Muñoz and Fedele, 2011a), including:

- Themes of the storylines shown,

- Types of conflicts shown,

- Types of conflict resolution,

- Character narrative role in resolving the conflict (based on Greimas, 1966; Luzón-Fernández et al., 2009).

This phase was implemented in January and February 2014.

7) Phase 7. Triangulation. Analysis and cross-checking of data obtained. This phase consisted of quantitative analysis carried out with SPSS as with the qualitative 
analysis of the list of characters, which was done with the program Atlas.ti. It was carried out between March and July 2014, ending with results cross-checking.

8) Phase 8. Writing of the final report. This final report was written in August and September 2014.

9) Phase 9. Dissemination. In parallel with the various abovementioned phases, project results were shared in two international conferences (Fedele, 2014a and 2014b): one in January 2014 (IV Congreso Internacional de la Sociedad Española de Investigación en Comunicación [4th International Conference of the Spanish Society of Communications Research]) and another in November 2014 (5th ECREA European Communication Conference Lisboa $2014^{1}$.

\section{Table 1. Calendar}

\begin{tabular}{|c|c|c|c|c|c|c|c|c|c|c|c|c|}
\hline \multirow[b]{2}{*}{$\begin{array}{l}\tilde{f} \\
\stackrel{0}{0} \\
\sum\end{array}$} & \multicolumn{4}{|l|}{$\begin{array}{l}\overrightarrow{-1} \\
\text { ư⿱ } \\
\text { 竞 }\end{array}$} & $\begin{array}{l}\text { 岀 } \\
\underline{\underline{y}} \\
\text { 咅 }\end{array}$ & 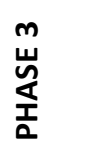 & 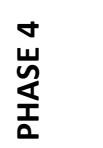 & $\begin{array}{l}\text { 足 } \\
\text { 岇 } \\
\text { 咅 }\end{array}$ & 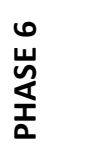 & $\begin{array}{l}\text { 岀 } \\
\text { 侖 } \\
\text { I }\end{array}$ & $\begin{array}{l}\infty \\
\text { 岁 } \\
\text { 公 }\end{array}$ & $\begin{array}{l}\text { 岁 } \\
\underline{\underline{x}} \\
\frac{1}{a}\end{array}$ \\
\hline & 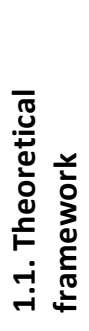 & 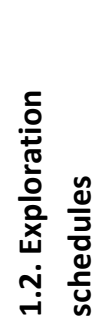 & 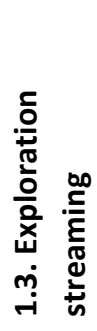 & 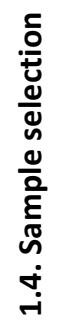 & 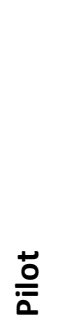 & 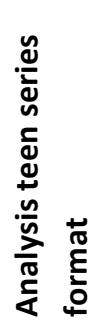 & 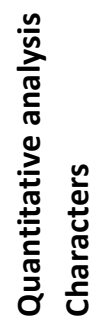 & 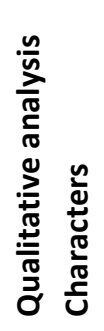 & 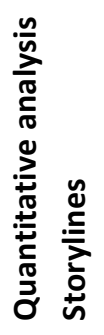 & 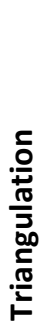 & $\begin{array}{l}\frac{5}{0} \\
\frac{0}{0} \\
\propto\end{array}$ & 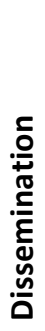 \\
\hline $10 / 12$ & $x$ & & & & & & & & & & & \\
\hline $11 / 12$ & $x$ & & & & & & & & & & & \\
\hline $12 / 12$ & $X$ & & & & & & & & & & & \\
\hline $01 / 13$ & & $x$ & $x$ & & & & & & & & & \\
\hline $02 / 13$ & & $x$ & $x$ & & & & & & & & & \\
\hline $03 / 13$ & & & & $x$ & & & & & & & & \\
\hline
\end{tabular}

\footnotetext{
${ }^{1}$ Part of the Project results have been spread and published after the two-years-grant:

- Fedele, M. (2015). Slim and curvy girls, slim and muscular boys: adolescents' portrayals in current teen series broadcast in Spain. ECREA Gender \& Communication Symposium 2015. Tarragona, Spain.

- Fedele, M., and Jiménez-Morales, M. (2016). Delgadas, a la moda y responsables: representación de las adolescentes en las series juveniles emitidas en España. V Congreso Internacional AE-IC Madrid 2016. Madrid, Spain.

- Masanet, M-J, and Fedele, M. (2019). El 'chico malote' y la 'chica responsable'. Adolescencia, modelos aspiracionales y teen series españolas. Palabra Clave, 22(2), 1-27
} 


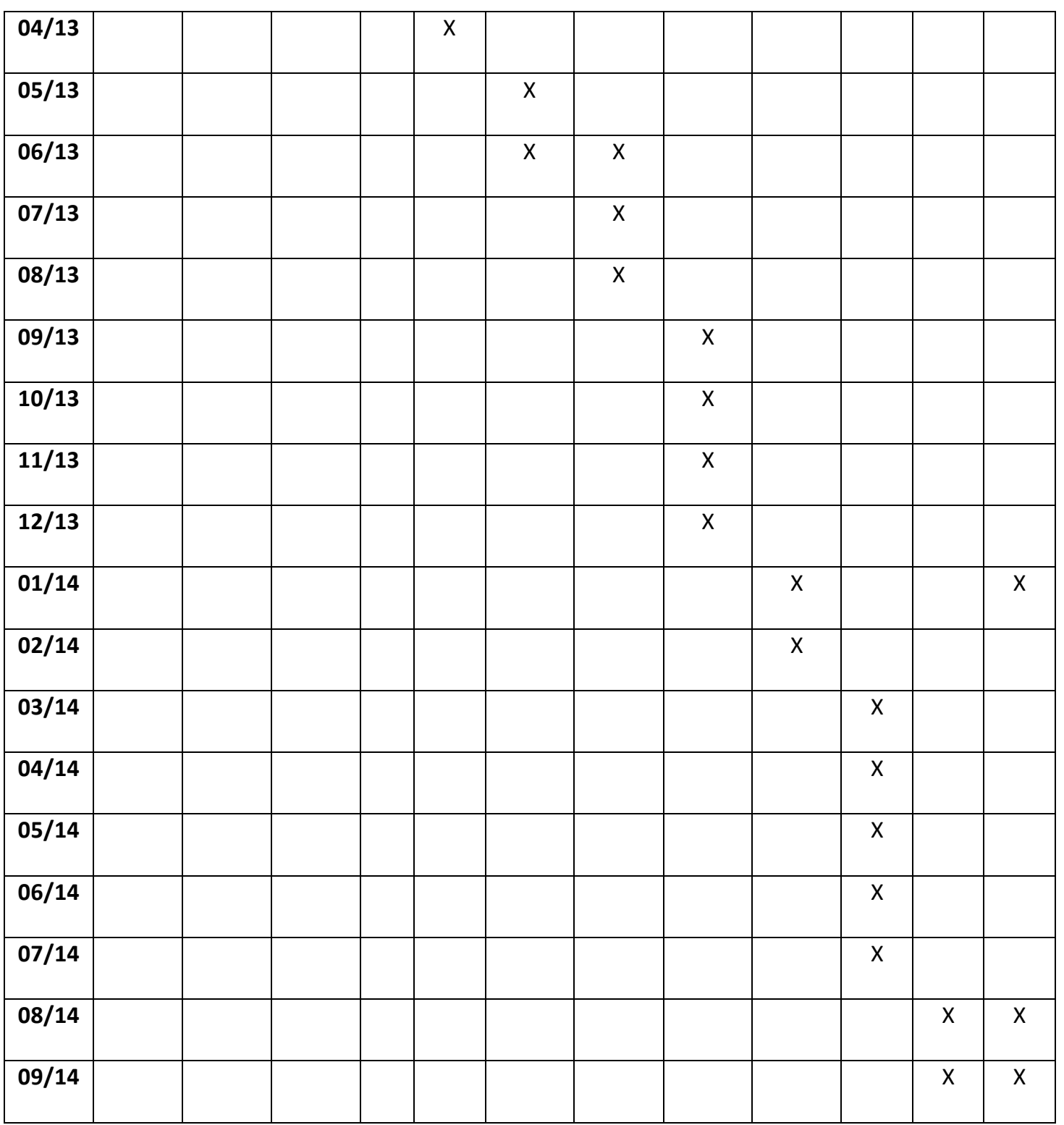




\section{RESULTS}

\subsection{Analysis of the teen series format}

The 40 titles chosen throughout the first phase of the methodological design are distributed as follows, by country of origin:

- 10 Spanish programmes (25\%): El Internado (Antena3, 2007-2010), 18RDC (Antena3, 2008-2009), Física o Química (Antena3, 2008-2011), 90-60-90 (Antena3, 2009), El pacto (Telecinco, 2010), No soy como tú (Antena3, 2010), Los Protegidos (Antena3, 2010-2012), Ángel o demonio (Telecinco, 2011), El barco (Antena3, 2011-2013), Polseras Vermelles (TV3, 2011-2013).

- 24 US programmes (60\%): The Gilmore Girls (WB, 2000-2007), Smallville (WB, 2001-2011), The O.C. (Fox, 2003-2007), One Tree Hill (WB, 2003-2012), Life as we know it (ABC, 2004-2005), Veronica Mars (UPN, 2004-2007), South of Nowhere (TeenNick, 2005-2008), Beyond the break (The N, 2006-2009), Kyle XY (ABC Family, 2006-2009), Friday Night Lights (NBC, 2006-2011), Gossip girl (The CW, 20072012), Terminator: the Sarah Connor chronicles (Fox, 2008-2009), 90210 (The CW, 2008-2013), The secret life of the American teenager (ABC Family, 2008-2013), 10 things I hate about you (ABC Family, 2009-2010), Make it or break it (ABC Family, 2009-2012), Glee (Fox, 2009-), The vampire diaries (The CW, 2009-), Pretty little liars (ABC Family, 2010-), Skins US (MTV, 2011), The Nine lives of Chloe King (ABC Family, 2011), The secret circle (The CW, 2011), Akward (MTV, 2011-), Teen wolf (MTV, 2011-).

- 6 British programmes (15\%): Skins (E4, 2007-2013), Britannia High (ITV, 2008), Merlin (BBC One, 2008-2012), Demons (ITV, 2009), Misfits (E4, 2009-), Premface (BBC Three, 2012-2013).

Of these, $10 \%$ (four programmes) were not broadcast on Spanish channels during the five-year period analysed, but were readily available to audiences on streaming and downloading websites.

The original broadcast of the teen series analysed occurred between the years 2000 and 2013; the oldest was The Gilmore Girls (US) and the most recent was Premface 
(UK). Both the number of seasons and the number of episodes vary widely depending on genre and country of production. For example, the Spanish fantasy miniseries No soy como tú only contained two episodes, while the US science fiction series Smallville contained 218 episodes over 10 seasons.

Episode duration also varies enormously, especially between countries, from 20 minutes for comedy series like Awkward to 115 minutes for the Spanish drama 90-6090.

As regards production, the US companies Warner Bros (8 titles), $A B C$ (6 titles) and MTV Productions (4 titles) lead the list in teen series production. Broadcast channels showed more variety, since each production company possesses various television channels to reach a teen audience. For example, Warner Bros broadcasts teen series on The $W B$, The $C W$ and $U P N ; A B C$ broadcasts theirs on $A B C$ and (especially) $A B C$ Family; and MTV Productions broadcasts on MTV, TeenNick and The N.

The situation is more balanced in the UK: two of the six titles analysed were broadcast on public television ( $B B C$ One and $B B C$ Three), two were broadcast on the private channel ITV, and two were broadcast on E4, a private channel of the Channel Four Television Corporation. The production companies vary in each case.

In Spain, on the other hand, the channel Antena3 broadcasts the majority of local teen series (7 of 10). However, this production is outsourced to various Spanish audiovisual production companies, including Globomedia and Ida y vuelta. If we also include US and UK series broadcast in Spain, the Atresmedia group (Antena3 and Neox) broadcasts $22.5 \%$ of the teen series in the sample, followed by the group Mediaset España (Telecinco and Cuatro) and MTV España, with 17.5\% each, and RTVE (La2 and ClanTV) at $12.5 \%$. Regional channels (TV3 in Catalonia, Canal Sur in Andalusia and ETB in the Basque Country) each broadcast 4 of the titles analysed (10\%), as did the forpay channels mentioned above. It is also worth emphasizing that part of the weight of the Atresmedia group is due to the fact that Neox has broadcast titles which were already premiered on other channels, as with their own Los Protegidos (Antena3, 2010-2012), TV3's Polseres Vermelles, The O.C. (US), which premiered in Spain on Clan TV, and One Tree Hill (The WB, 2003-2012, which premiered in Spain on La2). 
Regarding the programming slot in which they were originally broadcast, the majority of the teen series analysed (65\%) appeared during prime time, $22.5 \%$ were broadcast in the late fringe, and $7.5 \%$ were broadcast in the early fringe. The remaining $5 \%$ were broadcast in a variety of programming slots.

Regarding genre, series predominate (62.5\%), especially for US (70.8\%) and UK (83.3\%) products, followed by serials $(30 \%)$, the format used by half of the Spanish products (50\%), and, in last place, miniseries (7.5\%), in the case of two Spanish and one British production.

The most frequent microgenres are drama (40\%) and fantasy/science fiction (32.5\%), which illustrates two typical tendencies in teen series formats, the use of both realism and fantasy metaphors to narrate adolescence.

Regarding the type of protagonism of the 40 series analysed, one fourth of them have only one protagonist, while the rest feature a group of protagonists. On the other hand, the number of main characters, 378 in total, varies from 6 to 18 per series; 188 are male and 190 are female (although there are up to 10 male main characters in a single series against 8 female).

Regarding the age ranges of main characters, as expected, teenagers predominate (59.8\%).

Indeed, narrative protagonism for teenagers is prevalent in $85 \%$ of the teen series studied, especially in products from the US (only in one do teens share protagonism with other age groups). On the other hand, in $37.4 \%$ of cases other young age groups (youth proper as well as young adults) also have significant narrative importance in the stories narrated, although this does not mean teens lose their protagonism.

Regarding locations, they were analysed according to the screen minutes of a random episode from each series. The most frequent ones are domestic (almost 40\%) and educational (schools and various other educational centres) (30.5\%), even if public spaces (streets, squares, forests) are quite present too (14.3\%). 
Lastly, it bears mentioning that various cross-media distribution and 360 marketing strategies have been implemented for most of the titles analysed, increasingly so for more recent productions:

- Official DVDs (95\%);

- $\quad$ Official websites (70\%);

- Streaming availability on the official website (50\%);

- Social network presence (Facebook, Twitter, etc.) (47.5\%);

- Official merchandising (52.5\%);

- Smartphone apps (20\%);

- Official videogames (15\%);

- Official newsletter (10\%);

- Other (board games, books, spinoffs, blogs, comics, webisodes, TV specials, CDs, among others). 


\subsection{Analysis of teen characters}

A total of 130 protagonists were analysed from the 20 teen series selected for phases 4 and 6. Three variable types were measured for these characters: physical, sociodemographic and psychological characteristics.

Regarding physical characteristics, a small difference in gender was observed: $53.1 \%$ were male and $46.9 \%$ female. As in previous studies, female characters were underrepresented in comparison to male characters. Regarding age, given that the only ranges considered were tween (10-13), teen (14-19) and youth (20-25), the characters analysed were distributed as followed: $0.8 \%$ tweens, $88.5 \%$ teen and $10.8 \%$ youth. As for race, there is a clear predominance of Caucasian (84.6\%), followed distantly by black (6.9\%), Latino (3.1\%) and Asian (5.4\%). As in previous studies, white people are overrepresented in television shows.

As for physical build, thin figures abound (39.2\%), especially for female characters $(p<0.001)$ : more than half of female characters are thin. Although $36.9 \%$ of the characters analysed have average builds, heavyset $(2.3 \%)$ and very heavyset $(0.8 \%)$ builds are underrepresented. Remaining characters match two categories created ad hoc for this analysis: muscular (16.9\%), nearly exclusively male, and "thin with curves" (3.8\%), a category associated to female characters, often Latinas. The majority of characters (43.8\%) dress casually (jeans or slacks with informal t-shirts) or trendily (following fashion) (24.6\%), the latter category associated largely with female characters $(p=0,017)$. Also of note is that one fifth of characters wore some type of uniform (usually for school), although, qualitatively, it seemed that most adapt their uniform to their personal style (more classic, more trendy, more casual, etc.).

Regarding sociological traits, upper and upper-middle class characters were overrepresented (36.2\%), with $41.5 \%$ middle class. What is more, hardly $10 \%$ of characters seemed to have financial problems. Regarding family configurations, traditional nuclear families (parents with one or more children) remain predominant at $43.8 \%$. One fifth of the characters, on the other hand, live with one parent (with or without siblings), while $6.2 \%$ live with other family members. $18.5 \%$ live in a hall of 
residence/boarding school/dormitory or similar lodging, while the rest live in other situations (for example, in an apartment shared with peers, or alone).

Only $3.8 \%$ of the sample is homosexual; the majority is heterosexual. Of the homosexual minority, only one character is a girl. Regarding free time pursuits (what characters do when not working or studying), a large majority pursues social relations (68.5\%): in other words, going out with friends or girl/boyfriends and spending time with family.

Lastly, regarding psychological characteristics, the "big five" model (McCrae and Costa, 1999) was used to assign a dominant trait to each character, followed by numerical values ( 1 =very strongly disagree, $5=$ very strongly agree) for each remaining personality dimension. Results show a greater presence of characters with agreeableness (28.5\%) as their dominant trait, followed by neuroticism (26.9\%), extroversion (21.5\%), openness to experience (17.7\%) and conscientiousness (5.4\%). Statistical analysis of the scales of secondary traits paints a much more nuanced picture of the characters, who often seem to possess high degrees of apparently contradictory personality traits. Means $(x)$ and modes $(M)$ for the five traits are shown in Table 2.

Table 2. Personality Traits Means and Modes

\begin{tabular}{|l|l|l|}
\hline Personality Trait & Mean (x) & Mode (M) \\
\hline Agreeableness & 3.45 & 4 \\
\hline Extroversion & 3.12 & 4 \\
\hline Neuroticism & 3.01 & 1 \\
\hline Openness to experience & 2.98 & 1 \\
\hline Conscientiousness & 2.72 & 1 \\
\hline
\end{tabular}

Surprisingly, there are no significant gender differences regarding these psychological variables, except for conscientiousness, where female characters scored higher $(p=0,001)$, that means, they tend to be more responsible than male characters. 
Lastly, based on typical categories from the English-speaking film and TV industry, various youth archetypes were attributed to the characters in the sample, and were distributed as follows:

a) Male archetypes:

- $\quad$ The good guy (13.8\%);

- $\quad$ The rebel (12.3\%)

- $\quad$ The jock (10.8\%)

- The funny guy $(6.2 \%)$

b) Female archetypes:

- $\quad$ The beauty $(13.1 \%)$

- $\quad$ The popular girl (11.5\%)

- $\quad$ The independent girl (6.9\%)

- $\quad$ The basket case $(5.4 \%)$

- $\quad$ The honours student $(4.6 \%)$

- $\quad$ The best friend (2.3\%)

c) Gender-neutral archetypes:

- The geek (11.5\%)

- $\quad$ The manipulator (1.5\%)

The qualitative phase of the study helped nuance these results, especially in the case of the US series analysed (The Vampire Diaries), since, within the span of a season, most characters develop and show rather complex personalities, which often contradict the youth archetypes set by the audio-visual industry. Nonetheless, the complexity of characters from The Vampire Diaries was greater than that of those from El Barco, who were both flatter and often less inclined to develop in complex 
ways. A clear example is the character Caroline Forbes (The Vampire Diaries), who initially matches the popular girl archetypes, but turns out to be deep, responsible and very kind to her friends and others, showing concern and responsibility for them, and who is often the one to solve their problems. Another example is Matt Donovan, the jock of the series, who breaks the typical archetype of the athlete, for being a caring, loving and sensitive boy.

Those that do not develop much are female characters matching the beauty type. Both Ainhoa (EI Barco) and Elena (The Vampire Diaries) are shown as pretty, responsible, concerned for others, highly loyal and generous, and they do not change. They are always the "good characters" and often have to deal with problematic boyfriends (rebels with a high dose of neuroticism), whom they attempt to guide and change, following their ethics and values. Also, these two female heroines can be considered a mixing between the beauty and the honours student archetypes, since they also are very good students. The new archetype is one of a super-princess, since she is both pretty an intelligent.

On the other hand, the mal heroes do not match completely with the "good guy" archetype. Even if Stefan from The Vampire Diaries is sort of a good guy, but he is also tormented, especially by his hunger for blood (he is a "good" vampire who does not want to feed on humans) and by his evil brother Demon (a mixing of rebel and funny guy). Instead, Ulises from El barco is a clear example of rebel and troubled boy, impulsive and violent, but with a good heart for the people he loves.

Both series perpetuate the romantic ideal of love, as well as the narrative pattern of the redemptive love, based in the tale of the Beauty and the beats (Balló y Pérez, 1997).

In conclusion, even if new models and stereotypes appear both for girls and boys especially for their psychological traits, traditional stereotypes are still present in the teen series analysed for the physical characteristics. The portrayal of thin and curvy girls and of muscular boys is particularly worrying. 


\subsection{Analysis of the storylines}

Firstly, regarding storyline themes, interpersonal relationships predominate, particularly love $(33.8 \%)$, followed by friendship (8.5\%). In second place come intrigue/mystery storylines (15.4\%), especially related to certain microgenres like mystery. Storylines related to acceptance come in third place $(12.3 \%)$, and are developed through interior conflict $(p<0,001)$. Next come family problems $(10.8 \%)$, sex (6.2\%), while other themes add up to under $4 \%$.

Secondly, different origins can be identified for the conflicts shown. A social origin one connected to interpersonal relationships - is the most frequent (37.7\%). Next come romantic (19.2\%) and personal (19.2\%). Family can also be a source of conflicts (9.2\%), as can enemies (7.7\%), a category encompassing unknown enemies which the protagonists must struggle against, also a typical element of mystery series.

As for conflict type, exterior conflicts (56.2\%) predominate, in other words, those that develop through interaction with other characters.

Regarding conflict resolution, most protagonists tend to play an active part (54.6\%): in other words, they are proactive and struggle to resolve conflicts, even if they make mistakes. Only $16.2 \%$ are passive; the rest are neutral, a category frequently associated with characters experiencing "contextual" conflicts, storylines protagonised by other characters.

Lastly, the narrative role of most characters is that of subject of action (57.7\%), which corroborates the proactivity of most characters in conflict resolution.

It is interesting to note that no significant genre differences were found in narrative roles or in the types of conflict portrayed, offering a more equal gender representation in this sense. 


\section{Works Cited}

Arnett, J.J., Larson, R., and Offer, D. (1995). Beyond effects: adolescents as active media users. Journal of Youth and Adolescence, 24, 511-518.

Aubrey, J.S. (2004). Sex and Punishment: An Examination of Sexual Consequences and the Sexual Double Standard in Teen Programming. Sex Roles, 50 (7/8), 505-512.

Barriga, C.A., Shapiro, M.A., and Jhaveri, R. (2009). Media Context, Female Body Size and Perceived Realism. Sex Roles, 60, 128-141.

Belmonte, J., and Guillamón, S. (2008). Co-educar la mirada contra los estereotipos de género en TV. Comunicar, 31, 115-120.

Caldwell, J.T. (2004). Convergence television: aggregationg form and repurposing content in the culture of conglomeration, a L. Spigel, J. Olsson, Television after TV: essays on a medium in transition. Duke University Press.

Carlsson, U. (2006). In the service of young people? Studies and reflections on media in the digital age. Götenborg: Götenborg University.

Carrillo, M.V., Jiménez-Morales, M., and Sánchez, M. (2011). Media and Body Cult. Ciudad de México: Pearson.

Carrillo, M.V., Hernández, M., and Jiménez-Morales, M. (2011). Sociocultural and personal factors related to media and body cult that have an influence on young's wellbeing. Comunicación y Sociedad, XXIV, 227-252.

Davis, G., and Dickinson, K. (Eds.) (2004). Teen TV: Genre, Consumption, Identity. London: BFI.

Fedele, M. (2014b). Teen series in the digital era: similarities and differences mong American, British and Spanish Programmes. 5th ECREA Conference. Lisboa, Portual.

Fedele, M. (2014a). Características genéricas, temáticas y programáticas de la ficción seriada para jóvenes emitida en España. IV Congreso Internacional AE-IC “Espacios de comunicación”. Bilbao, Spain.

Fedele, M. (2011). El consum adolescent de la ficció seriada televisiva. Tesi doctoral. Departament de Comunicació Audiovisual i Publicitat. Universitat Autònoma de Barcelona.

Fedele, M. (2009b). Adolescents i teen series. Una aproximació teòrica. Treball de Recerca. Departament de Comunicació Audiovisual i Publicitat. Universitat Autònoma de Barcelona.

Fedele, M. (2009a). El espíritu glocal de MTV. La comunicación de la brand identity de MTV Italia. Área abierta, 24.

Fedele, M., and García-Muñoz, N. (2010). El consumo adolescente de la ficción seriada. Vivat Academia, $111,48-65$.

Fernández-Villanueva, C., Revilla-Castro, J.C., Domínguez-Bilbao, R., Gimeno-Jiménez, L., and Almagro, A. (2009). Gender Differences in the Representation of Violence on Spanish Television: Should Women be More Violent?. Sex Roles, 61, 85-100.

Figueras-Maz, M., Mauri-De Los Ríos, M., and Rodríquez-Martínez, R. (2013). Invisible, Stereotyped and Filtered by Adults: The Image of Young People in the Catalan News Media. Young, 21 (1), 77-93. 
Fouts, G., and Burggraf, K. (2000). Television situation comedies: female weight, male negative comments, and audience reactions. Sex Role, 42 (9/10), 925-932.

Fouts, G., and Vaughan, K. (2002). Television situation comedies: male weight, negative references, and audience reactions. Sex Roles, 46(11/12), 439-442.

Galán-Fajardo, E. (2007). Construcción de género y ficción televisiva en España. Comunicar, 28, 229-236

García-Muñoz, N., and Fedele, M. (2011a). Las series televisivas dirigidas al público juvenil. Tramas y conflictos representados en una «teen series». Comunicar, 37 (XIX), 133-140.

García-Muñoz, N., and Fedele, M. (2011b). Retrato de los adolescentes en la ficción televisiva. Un estudio de caso. Ámbitos, 20, 71-86.

García-Muñoz, N., and Fedele, M. (2011c). The Teen Series and the Young Target. Gender Stereotypes In Television Fiction Targeted to Teenagers. Observatorio (OBS*) Journal, 5(1), 215-226.

Garitaonandia, C., Juaristi-Larrinaga, P., Oleaga-Páramo, J.A., and Pastor-Ruíz, F. (1998). Las relaciones de los niños y de los jóvenes con las viejas y nuevas tecnologías de la información. Zer, 4, 131-161.

Gerbner, G., Gross, L., Morgan, M., Signorielli, N., and Shanahan, J. (2002). Growing up with television: Cultivation processes. In J. Bryant \& D. Zillmann (Eds.), LEA's communication series. Media effects: Advances in theory and research (p. 43-67). Lawrence Erlbaum Associates Publishers.

Glascock, J. (2001). Gender roles on prime-time network television: Demographics and behaviors. Journal of Broadcasting \& Electronic Media, 45, 656-669.

Gómez-Puertas L. (2011). El serial catalán como foro de debate social sobre la delincuencia contra la indemnidad sexual y la vida, la violencia doméstica y el acoso. En Sierra-Sánchez, J., Liberal-Ormaechea, S. (ed.) Reflexiones científicas sobre cine, publicidad y género desde la óptica audiovisual. Madrid: Fragua; 439-464.

Grandío-Pérez, M., and Pedro-González, P. (2009). La influencia de la Sitcom americana en la producción de comedias televisivas en España. El caso de 'Friends' y '7 vidas'. Ámbitos, 18, 83-97.

Greimas, A.J. (1966): Semántica Estructural. Madrid: Gredos.

Guarinos, V. (2009). Fenómenos televisivos «teenagers»: prototipias adolescentes en series vistas en España. Comunicar, 33, 203-211.

Heintz-Knowles, K.E. (2000). Images of youth: A Content Analysis of Adolescents in Prime-time Entertainment Programming. Washington, DC: Frameworks Institute.

Lauzen, M.M., Dozier, D.M., and Horan, N. (2008). Constructing gender stereotypes through social roles in prime-time television. Journal of Broadcasting \& Electronic Media, 52(2), 200-214.

Lauzen, M.M., Dozier, D.M., and Cleveland, E. (2006). Genre Matters: An Examination of Women Working Behind the Scenes and On-screen Portrayals in Reality and Scripted Prime-Time Programming. Sex Roles, 55, 445-455.

Livingstone, S. (1998). Mediated Childhoods. A Comparative approach to Young People's Changing Media Environment in Europe. European Journal of Communication, 13 (4), 435-456. 
Luzón-Fernández, V., Figueras-Maz, M., Capdevila-Gómez, A., Gómez-Puertas, L., Jiménez-Morales, M., and Ferrer-Rodriguez, I. (2009). La imagen de los y las adolescentes en el prime time televisivito. Transmisión, consumo y recepción. Informe de investigación. Instituto de la Mujer. Ministerio de Igualdad.

Madrigal-Fritsch, H., de Irala-Estévez J., Martínez-González M.A., Kearney J., Gibney M., MartínezHernández J.A (1999). Percepción de la imagen corporal como aproximación cualitativa al estado de nutrición. Salud Publica Mex, 41, 479-486.

Masanet, M-J., Medina-Bravo, P., and Ferrés, J. (2012). Representación mediática de la sexualidad en la ficción seriada dirigida a los jóvenes. Estudio de caso de 'Los Protegidos' y 'Física o Química'. Revista Internacional de Comunicación Audiovisual, Publicidad y Estudios Culturales, 1(10), 1537-1548.

Mastro, D.E., and Ortiz, M. (2008). A Content Analysis of Social Groups in Prime-Time Spanish-Language Television. Journal of Broadcasting and Electronic Media, 52(1), 101-118.

Mauri-De Los Ríos, M., and Figueras-Maz, M. (2012). Juventud y discurso mediático. El tratamiento periodístico de las personas jóvenes en los medios de Cataluña. Revista Mediterranea de Comunicación, 3, 39-58.

McCrae, R.R., and Costa P.T. (1999). A five-factor theory of personality. En L.A. Pervin y O.P. John (eds.), handbook of personality: theory and research. New York, Guildford Press.

Medina-Bravo, P., and Rodrigo, M. (2009). Análisis de la estructura narrativa del discurso amoroso en la ficción audiovisual. Estudio de caso: “Los Serrano” y “Porca Misèria”. ZER, 14 (27), 83-101.

Medrano-Samaniego, C., Palacios-Navarro, S., and Aierbe-Barandiarán, A. (2007). Los hábitos y preferencias televisivas en jóvenes y adolescentes: Un estudio realizado en el País Vasco. Revista Latina de Comunicación Social, 62, 53.

Meyer, M.D. (2003). 'It's me. I'm it'. Defining Adolescent Sexual Identity through Relational Dialectics in Dawson's Creek. Communication Quarterly, 51(3), 262-276.

Maira, S., and Soep, E. (2004). United States of Adolescence? Reconsidering US Youth Culture Studies. Young, 12 (3), 245-269.

Mosely, R. (2001). The Teen Series. In Creber, G. (Ed.), The Television Genre Book. London: BFI.

Pindado, J. (2006). Los medios de comunicación y la construcción de la identidad Adolescente. Zer, 21, 11-22.

Prado, E., and Delgado, M. (2010). La televisión generalista en la era digital. Tendencias internacionales de programación. Telos, 84.

Ramajo, N., Ferrer, I., Capdevilla, A., Figueras, M., Gómez, L., Jiménez, M., and Luzón, V. (2008). La presencia del adolescente en el prime time televisivo: objeto de interés en informativos, ficción y publicidad. Sphera Publica, 8, 191-212.

Ramírez de la Piscina, T., Zarandona, E., Basterretxea, J.I., and Idoiaga, P. (2006). Estudio sobre la alfabetización audiovisual de los adolescentes vascos: Recopilatorio de actitudes críticas y acríticas. Zer, 21, 177-202.

Robinson, T., Callister, M., and Jankoski, T. (2008). Portrayal of body weight on children's television sitcoms: A content analysis. Body Image, 5, 141-151. 
Rodrigo, M., and Medina, P. (2009). Análisis de la estructura narrativa del discurso amoroso en la ficción audiovisual. Estudio de caso: “Los Serrano" y “Porca Misèria”. Zer, 14 (27), 83-101.

Ross, S.M., and Stein, L.E. (Eds.) (2008). Teen television: Essays on programming and fandom. Jefferson, NC: McFarland.

Scharrer, E. (2001). Tough guys: the portrayal of hypermasculinity and aggression in televised police dramas. Journal of Broadcasting \& Electronic Media, 45 (4), 615-634.

Signorielli, N. (1987). Children and adolescents on television: A consistent pattern of devaluation. Journal of early adolescence, 7(3), 255-268.

Signorielli, N., and Bacue, A. (1999). Recognition and respect: A content analysis of prime-time television characters across three decades. En: Sex Roles, 40(7-8), 527-544.

Spigel, L., Olsson, J. (2004). Television after TV: essays on a medium in transition. Duke University Press.

Von Feilitzen, C. (Ed.) (2004), Young People, Soap Operas and Reality TV. Göteborg: Nordicom, Götenborg University.

Ward, L. M. (1995). Talking about sex: Common themes about sexuality in the prime-time television programs children and adolescents view most. Journal of Youth and Adolescence, 24 (5), 595. 


\section{Annexes}

7.1. Annex 1. List of the teen series analysed in phase 3.

\begin{tabular}{|c|c|}
\hline $\begin{array}{l}\text { SPAIN: } \\
\text { 1. Física o Química } \\
\text { 2. El Internado } \\
\text { 3. Los Protegidos } \\
\text { 4. El Barco } \\
\text { 5. Polseres Vermelles } \\
\text { 6. No soy como tú } \\
\text { 7. } 18 \\
\text { 8. 90-60-90 } \\
\text { 9. Ángel o demonio } \\
\text { 10. El pacto } \\
\text { UK: } \\
\text { 35. Skins } \\
\text { 36. Pramface } \\
\text { 37. Britannia High } \\
\text { 38. Merlin } \\
\text { 39. Misfits } \\
\text { 40. Demons }\end{array}$ & $\begin{array}{l}\text { US: } \\
\text { 11. The Gilmore girls } \\
\text { 12. The O.C. } \\
\text { 13. Veronica Mars } \\
\text { 14. Smallville } \\
\text { 15. KyleXY } \\
\text { 16. Gossip Girl } \\
\text { 17. 90210 } \\
\text { 18. The secret life of the American } \\
\text { teenager } \\
\text { 19. Terminator, Sarah Connor's } \\
\text { chronicles } \\
\text { 20. Glee } \\
\text { 21. The vampire diaries } \\
\text { 22. Teen wolf } \\
\text { 23. Pretty Little Liars } \\
\text { 24. Awkward } \\
\text { 25. One tree hill } \\
\text { 26. I0 things I hate about you } \\
\text { 27. Skins USLife as we know it } \\
\text { 28. Life as we know it } \\
\text { 29. Beyond the break } \\
\text { 30. Friday Night Lights } \\
\text { 31. Make it or break it } \\
\text { 32. The nine lives of Chloe King } \\
\text { 33. South of Nowhere } \\
\text { 34. The secret circle }\end{array}$ \\
\hline
\end{tabular}




\subsection{Annex 2. List of teen series analysed in phases 4 and 6.}

\begin{tabular}{|c|c|}
\hline SPAIN: & \multirow{7}{*}{$\begin{array}{l}\text { US: } \\
\text { 6. Smallville } \\
\text { 7. KyleXY } \\
\text { 8. Gossip Girl } \\
\text { 9. } 90210 \\
\text { 10. The secret life of the American } \\
\text { teenager }\end{array}$} \\
\hline 1. Física o Química & \\
\hline 2. El Internado & \\
\hline 3. Los Protegidos & \\
\hline 4. El Barco & \\
\hline 5. Polseres Vermelles & \\
\hline UK: & \\
\hline 16. Skins & 11. Glee \\
\hline 17. Pramface & 12. The vampire diaries \\
\hline 18. Britannia High & 13. Teen wolf \\
\hline 19. Merlin & 14. Pretty Little Liars \\
\hline 20. Misfits & 15. Awkward \\
\hline
\end{tabular}




\subsection{Annex 3. List of teen series characters analysed.}

\begin{tabular}{|c|c|c|}
\hline Country & Teen series & Character \\
\hline \multirow[t]{32}{*}{ Spain } & \multirow[t]{10}{*}{ Física o Química } & Yoli \\
\hline & & Fer \\
\hline & & Paula \\
\hline & & Gorka \\
\hline & & Julio \\
\hline & & Ruth \\
\hline & & César \\
\hline & & Cova \\
\hline & & Isaac \\
\hline & & Jan \\
\hline & \multirow{5}{*}{ El Internado } & Marcos \\
\hline & & Vicky \\
\hline & & Iván \\
\hline & & Carolina \\
\hline & & Roque \\
\hline & \multirow[t]{5}{*}{ Los protegidos } & Culebra \\
\hline & & Sandra \\
\hline & & Lucas \\
\hline & & Claudia \\
\hline & & Leo \\
\hline & \multirow[t]{7}{*}{ El Barco } & Ainhoa \\
\hline & & Ulises \\
\hline & & Vilma \\
\hline & & Palomares \\
\hline & & Piti \\
\hline & & Ramiro \\
\hline & & Estela \\
\hline & \multirow[t]{5}{*}{ Polseres vermelles } & Lleó \\
\hline & & Jordi \\
\hline & & Ignasi \\
\hline & & Cristina \\
\hline & & Toni \\
\hline \multirow[t]{19}{*}{ US } & \multirow[t]{6}{*}{ Smallville } & Clark \\
\hline & & Lana \\
\hline & & Whitney \\
\hline & & Pete \\
\hline & & Chloe \\
\hline & & Lex \\
\hline & \multirow[t]{6}{*}{ Kyle XY } & Kyle \\
\hline & & Lory \\
\hline & & Josh \\
\hline & & Declan \\
\hline & & Amanda \\
\hline & & Charlie \\
\hline & \multirow[t]{6}{*}{ Gossip girl } & Serena \\
\hline & & Blair \\
\hline & & Dan \\
\hline & & Nate \\
\hline & & Chuck \\
\hline & & Jenny \\
\hline & 90120 & Annie \\
\hline
\end{tabular}




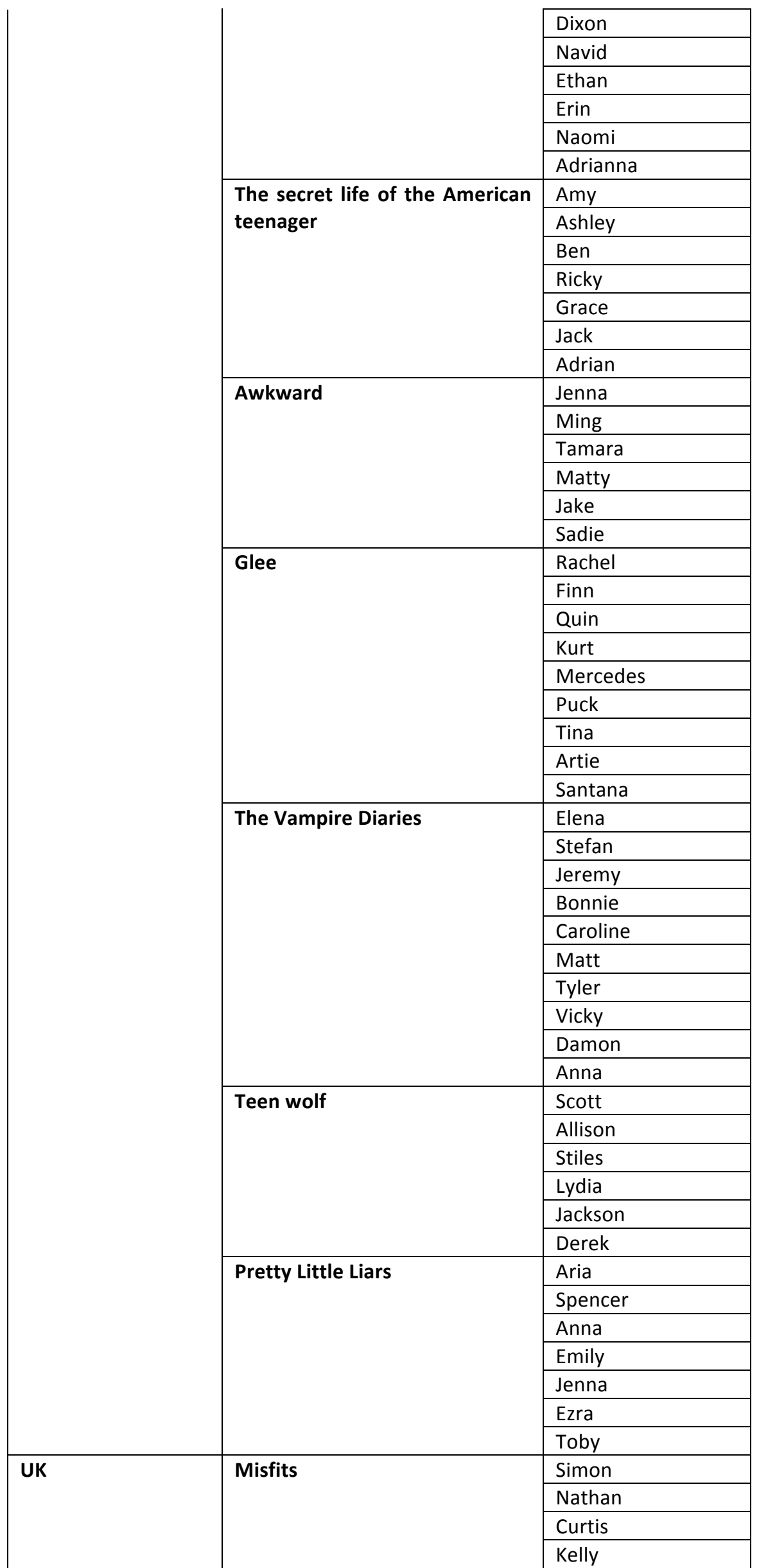




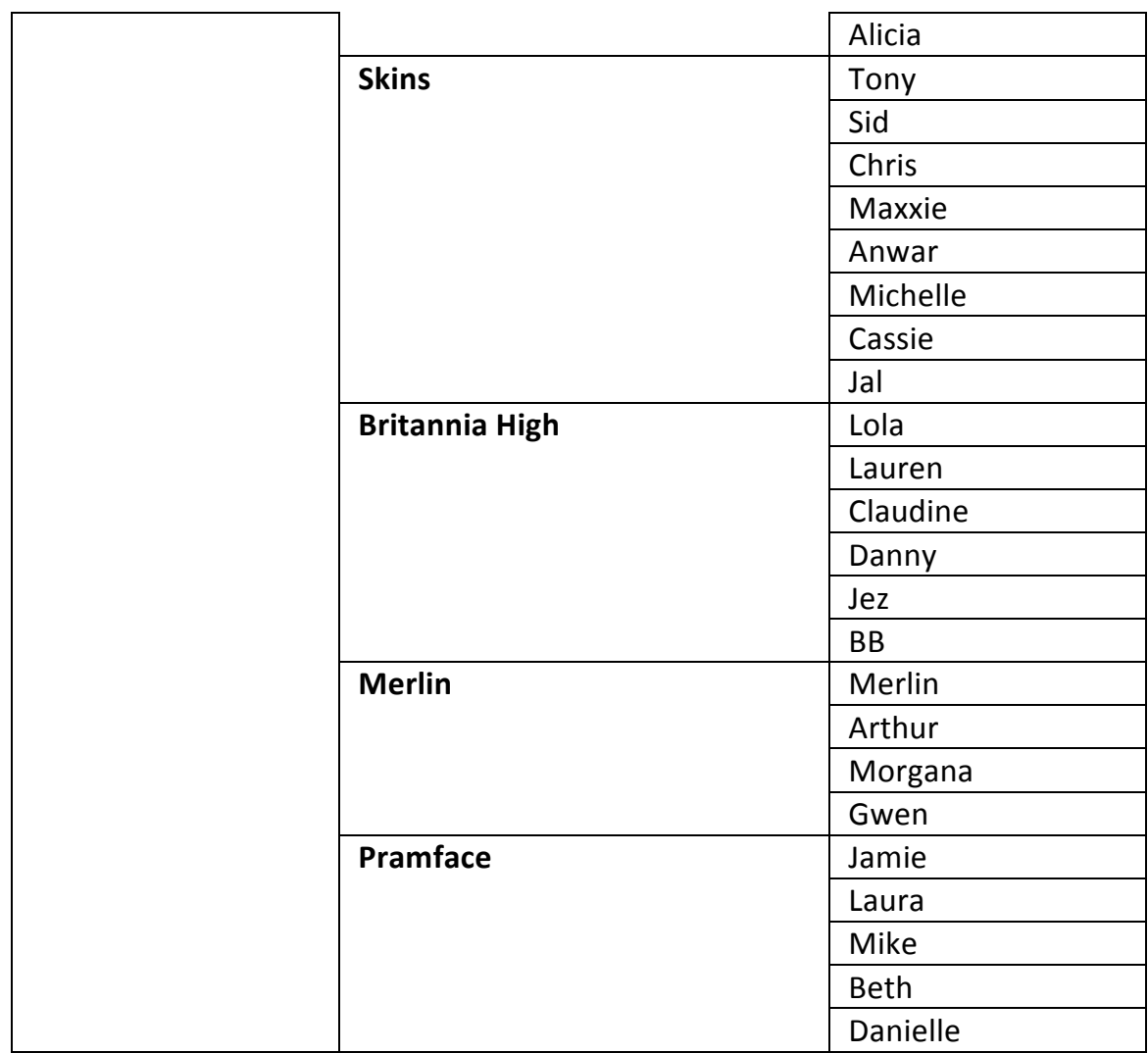




\subsection{Annex 4. Coding system for teen series}

1) Title of the programme in its original language

2) Country of origin (1=Spain; $2=U S ; 3=U K)$

3) Years = years of original broadcast YYYY-YYYY)

4) Production = name of the production company/network

5) NetworkOR = name of network of the original broadcasting

6) SLOT of broadcasting, according to Euromonitor

\begin{tabular}{|l|l|l|l|}
\hline & Spain & US & UK \\
\hline 1. Early morning / Morning & $7: 00-13: 30$ & $7: 00-12: 00$ & $6: 00-11: 30$ \\
\hline 2. Midday & $13: 30-15: 30$ & $12: 00-16: 00$ & $11: 30-14: 00$ \\
\hline 3. After lunch & $15: 30-18: 00$ & & $14: 00-18: 30$ \\
\hline 4. Afternoon / Early Fringe & $18: 00-20: 30$ & $16: 00-20: 00$ & $18: 30-20: 00$ \\
\hline 5. Prime time & $20: 30-22: 30$ & $20: 00-23: 00$ & $20: 00-22: 30$ \\
\hline 6. Late night & $22: 30-1: 00$ & $23: 00-1: 00$ & $22: 30-1: 00$ \\
\hline 7. Overlap Prime time and Late night & \multicolumn{2}{|l|}{ 8. Overlap After lunch and Afternoon } \\
\hline 9. Different slots & 10. Overlap Afternoon and Prime Time \\
\hline
\end{tabular}

7) $E S P=$ broadcast in Spain (1=yes, 2=no)

8) NetworkESP = name of the Spanish network of broadcast (for UK and US programmes)

9) NetworkESPcompany = name of the media company to which the NetworkESP belongs

10) SlotESP = slot of broadcast in Spain (for UK and US programmes)

11) Genre = Euromonitor's categories (1=series; $2=$ serial; $3=$ sitcom; $4=$ miniseries)

12) Microgenre $=$ Euromonitor's categories (1=drama; $2=$ comedy; $3=$ fantasy/Sci-fi; $4=$ =adventure/action; $5=$ musical comedy; $6=$ thriller/suspense; $7=$ horror)

13) Target ( $1=$ Tweens; $2=$ teens; $3=y o u n g$ adults; $4=$ Tweens+teens; $5=$ teens+young adults; $6=$ tweens+teens+young adults; 7=familiar; $8=$ tweens+teens+adults)

14) Seasons = number of seasons broadcast until 2012

15) Episodes = number of episodes broadcast until 2012

16) Average duration of each episode (in minutes)

17) NProts = number of protagonists

18) NameProts =names of protagonists, separated by comas

19) NMainCharacters = number of protagonists + main characters

20) MenMain = number of male main characters

21) WomenMain = number of female main characters

22) TweensMain = number of tween main characters $(10 / 13$ years old $)$

23) TeensPrinc $=$ number of teen main characters ( $14 / 19$ years old)

24) YoungMain = number of young main characters $(20 / 25$ years old $)$

25) YoungAdultMain = number of young adult main characters $(25 / 35$ years old $)$

26) OtheragesMain = number of main characters of other ages (adults, old people, children)

27) TypeProtagonism ( $1=$ Individual; $2=$ Group/Choral)

28) WeightYoungAdult $=$ narrative weight of young and young-adult characters ( $1=y e s, 2=$ no $)$

29) ProtagonismTeens $=$ narrative weight of teens compared to young and young-adult characters ( $1=$ greater; 2=equal; 3=lower)

30) Strategy360DVD (1=yes, $2=$ no)

31) Strategy360WEB (1=yes, $2=$ no)

32) Strategy360SocialNetworks( $1=y e s, 2=n o$ )

33) Strategy 360 Merchandising $(1=y e s, 2=n o)$

34) Strategy360MobileAPP (1=yes, $2=$ no)

35) Strategy 360 Magazine ( $1=y e s, 2=n o)$

36) Strategy360Videogame (1=yes, $2=$ no)

37) Strategy360Streaming ( $1=y e s, 2=$ no)

38) Strategy3600ther ( $1=y e s, 2=n o)$

39) SpacePUB = Outside/Exterior public spaces (urban and/or not urban) in minutes

40) SpaceHOME = Domestic spaces in minutes

41) SpaceSCHOOL = Educative centres in minutes

42) SpaceWORK = Work places in minutes

43) SpaceRECRE = Recreational centres in minutes

44) SpaceOTHER $=$ Other spaces (medical centres, malls, police stations, etc.) in minutes 


\subsection{Annex 5. Coding system for space variables}

\begin{tabular}{|l|l|l|}
\hline \multirow{4}{*}{$\begin{array}{l}\text { OUTSIDE PUBLIC SPACES } \\
\text { (URBAN OR NOT) }\end{array}$} & Exterior spaces of cities, towns, etc. \\
\cline { 2 - 3 } & Public gardens & Cemetery \\
\cline { 2 - 3 } & Streets, squares & Forest \\
\cline { 2 - 3 } & Roofs & Car \\
\cline { 2 - 3 } & Beach & Public transport \\
\cline { 2 - 3 } & Port, dock & Other \\
\hline DOMESTIC SPACES & Kitchen & Bedroom \\
\cline { 2 - 3 } & Dining room & Laundry \\
\cline { 2 - 3 } & Living room & Garden, porch \\
\cline { 2 - 3 } & Hall, aisles & Terrace, balcony \\
\cline { 2 - 3 } & Bathroom & Other \\
\cline { 2 - 3 } & Basement, Garage & Several domestic spaces at once \\
\hline EDUCATIONAL CENTRES & School (general shot) & Outside spaces (parking, playground, \\
& & gardens, etc.) \\
\cline { 2 - 3 } & Classroom & Bathroom \\
\cline { 2 - 3 } & Aisles & Auditorium, Theatre, Art area \\
\cline { 2 - 3 } & Office & Library \\
\cline { 2 - 3 } & Cafeteria, Dining room & Gym/sport zone \\
\cline { 2 - 3 } & Locker room & Other \\
\hline OTHER SPACES & $\begin{array}{l}\text { Stores, cafeterias, bookshops, } \\
\text { etc. }\end{array}$ & Office \\
\cline { 2 - 3 } & Company & Other \\
\hline WORK PLACES & Restaurant, cafeteria, pub, etc. & Cinema, Theatre, Art gallery \\
\cline { 2 - 3 } & Disco, club & Other \\
\hline \multirow{5}{*}{ RECREATIONAL CENTRES } & Medical centres, malls, stores, shops, police station, church, etc. \\
\hline
\end{tabular}




\subsection{Annex 6. Coding system for teen characters}

\section{IDENTIFYING THE CHARACTER}

1) Name of the character

2) Title the programme in its original language

3) Country of origin (1=Spain; $2=U S ; 3=U K)$

4) Genre = Euromonitor's categories (1=series; $2=$ serial; $3=$ sitcom; $4=$ miniseries)

5) Microgenre = Euromonitor's categories (1=drama; $2=$ comedy; $3=$ fantasy/Sci-fi; 4=adventure/action; $5=$ musical comedy; 6 =thriller/suspense; $7=$ horror)

\section{PHYSICAL CHARACTERISTICS}

6) Sex (1=man; $2=$ woman; $3=$ other)

7) Age (1=tween, 8-13 years old; 2=teen, 14-19 years old; 3=young, 20-25 years old)

8) Race (1= Caucasian; 2=Afro-American; 3=Hispanic/Latin; 4= Asian; 5= Other)

9) Physical constitution (1=Thin/underweight $B M G<19,99 \rightarrow F 1, M 1-F 3, M 3 ; 2=$ Normal / normal weight $20<$ BMG<24,99 $\rightarrow$ F4,M4-F5,M5); 3=Heavyset / overweight $25<$ BMG<29,99 $\rightarrow$ F6,M6 - F7,M7; 4=Very heavyset/ obesity BMG>30= F8,M8 - F9,M9); 5=Muscular /only for boys: normal weight + muscles; $6=$ Curvy / only for girls: thin and with curves)

10) Clothing ( $1=$ Casual /jeans, t-shirts, etc.; $2=$ Classical / formal and conventional clothes; 3=Sports dress; 4=Trendy / in fashion; 5= Alternative fashion /e.g.: hippie, metal, gothic, etc.; $6=$ Uniforms).

11) Do they usually dress provocatively, that is girls showing curves and boys showing muscles? (1=yes, $2=$ no; 9=N.I.)

\section{SOCIOLOGICAL CHARACTERISTICS}

12) Social class ( $1=$ Upper, they belong to a rich family who can afford luxuries; $2=$ Upper-Middle, they belong to a family with no financial troubles and with a big house; $3=$ Middle, they do not need to work, since they belong to a family with no financial issues, with their own house; $4=$ Working, they belong to a family with some economic difficulties; $5=$ Low, they have to work to subsist or helping their families, who have several financial troubles; $9=$ N.I.)

13) Do they have financial troubles? (1=yes, $2=$ no; $9=\mathrm{N} . \mathrm{I}$.)

14) Type of family unity = the character lives with (1=parents; $2=$ parents+siblings; $3=$ single parent; $4=$ other relatives; $5=$ school residence $/$ boarding school/ similar; $6=$ other situation; $9=$ N.I.)

15) Sexual orientation (1=heterosexual; $2=$ homosexual; $3=$ bisexual; $4=$ other)

16) Leisure activities ( $1=$ Social relationships, that is hanging out with friends, dates, spending spare time with the family; 2=Diversion, that is parties, games, drinking, dancing, etc.; 3=Playing/listening to music; 4=Culture, e.g. books, arts, theatre, etc.; 5=Sports; 6=Politics/associations; $7=$ =Personal care; $8=$ Media; $9=$ Inactivity/resting; $10=0$ ther; $99=$ N.I.) 


\section{PSYCHOLOGICAL CHARACTERISTICS}

17) Personality $=$ pick the prominent factor (1=Neuroticism $\rightarrow$ sensitive/nervous vs. secure/confident; $2=$ =xtraversion $\rightarrow$ outgoing/energetic vs. solitary/reserved; 3=Openness to experience $\rightarrow$ Inventive/curious vs. consistent/cautious; 4=Agreeableness $\rightarrow$ friendly/compassionate vs. analytical/detached; $5=$ Conscientiousness $\rightarrow$ efficient/organized vs. easy-going/careless

18) Personality neuroticism $=$ mark the degree of agreement of this factor with character $(1=$ strongly disagree; $2=$ disagree; $3=$ neither agree or disagree; 4=agree; $5=$ strongly agree)

19) Personality extraversion $=$ mark the degree of agreement of this factor with character (1= strongly disagree; 2 = disagree; $3=$ neither agree or disagree; 4=agree; 5=strongly agree)

20) Personality openness to experience $=$ mark the degree of agreement of this factor with character (1= strongly disagree; $2=$ disagree; $3=$ neither agree or disagree; $4=$ agree; $5=$ strongly agree)

21) Personality agreeableness $=$ mark the degree of agreement of this factor with character ( $1=$

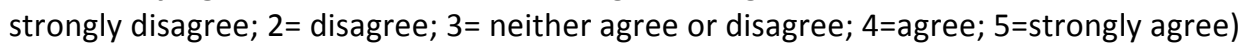

22) Personality conscientiousness $=$ mark the degree of agreement of this factor with character ( $1=$ strongly disagree; $2=$ disagree; $3=$ neither agree or disagree; $4=$ agree; $5=$ strongly agree)

23) Teen archetype (1=The "good guy", normally the protagonist, loyal, idealistic, honest, forgiving, who cares about others and always does the right thing, etc.; $\mathbf{2 = T h e ~ R e b e l / T h e ~ c r i m i n a l ~ / T h e ~}$ Troubled, usually the antagonist, the one who by his will or his incapacity always messes up. There are different variants: the criminal, more violent and oriented to commit crimes (even if they are only ideal) against authority; the troubled/tormented, who needs to be saved from himself and his dark inner side; sometimes even the funny one works like a rebel; 3=The Funny one, the one who messes it up but in a fun way, the life of the party, the one who always thinks of having a good time and taking advantage of the moment, also the silly one. He does not have to be rebellious, but normally he occupies that role, in a funny version. Often, in fact, he uses humour as a way of defending his fears and his inner world; 4=The Jock/The athlete, usually plays on the high school team or any other sports, is muscular and is the most popular boy in high school. The most common version is the silly, popular, smug and pushy athlete; 5=The Geek (includes The Nerd/The Brain), they are nerds or geeks, they usually stand out in something (studies, music, technology, media,...). Normally they do not belong to the popular group but may end up being part of it. They are also often best friends with the protagonists; $6=$ The Princess/The Beauty, usually the female protagonist or the beloved of the protagonist, the beautiful and almost always good girl (although she does not seem so), with which to crown his dream. She is often more an object than a subject of actions; $7=$ The popular girl, the most popular girl in the institute, the one who leads the group of the popular ones, trendsetter, often rich and flawed and even silly, only cares about fashion and the like, often the girlfriend of the high school team captain (the jock). 8=The straight " $A$ "/ Honours student, the first of her class, she often needs a scholarship to continue her studies, intelligent and brilliant, responsible, she usually helps the protagonist to study. 9=The basket case, "someone or something that is incapable of functioning normally", they are not properly a rebel, although it may seem so, because they are usually more introverted and self-destructive (although from a lighter and self-ironic point of view); 10=The independent girl, a more feminist girl model, a girl who takes responsibility for a lot, or who decides to go against fashion but intelligently (not in a rebellious way). Unlike the other female stereotypes, she is not (as) hanging on or as in need of a male counterpart to realize her deep goals as a character. 


\section{STORYLINES / PLOTS}

24) Storyline theme (1=Friendship; $2=$ Love; $3=$ =Family problems; $4=$ Sex; $5=$ Self-acceptance; 6=Professional goals/expectations; 7= Drugs; 8=Discrimination; 9=Violence; 10=Health; 11=Suspense/Mystery; 99=The character cannot be associated to any plot)

25) Origin of the plot/conflict ( $1=$ Love; $2=$ Other social relationship; $3=$ Family; $4=$ Personal/inner; $5=$ Financial; $6=$ Antagonists; $99=$ The character cannot be associated to any plot)

26) Type of conflict ( $1=$ Interior/Inner; $2=$ =xternal/Social; $3=$ Contextual/of others, that means the characters is not the protagonist of the storyline; $99=$ The character cannot be associated to any plot)

27) Role of the character in the conflict resolution (1=Active; $2=$ Neutral; $3=$ Passive; $99=$ The character cannot be associated to any plot)

28) Narrative role ( $1=$ Subject of action and of state; $2=$ Subject of action but not of state; $3=$ Subject of state of another subject of action; 4=Sender; 5=Object; 6=Helper; 7=Opponent; 8=Receiver/Sanctioner) 